\title{
Modeling identifies optimal fall planting times and irrigation requirements for canola and camelina at locations across California
}

Sufficient rainfall and appropriate soil temperatures during the canola planting window occur
statewide on average 1 in 3 years, but camelina is significantly more drought and cold tolerant.

by Nicholas George, Lucia Levers, Sally Thompson, Joy Hollingsworth and Stephen Kaffka

\section{Abstract}

In California, Brassica oilseeds may be viable crops for growers to diversify their cool-season crop options, helping them adapt to projected climate change and irrigation water shortages. Field trials have found germination and establishment problems in some late-planted canola, but not camelina at the same locations. We used computer modeling to analyze fall seedbed conditions to better understand this phenomenon. We found seedbeds may be too dry, too cold, or both, to support germination of canola during late fall. Based on seedbed temperatures only, canola should be sown no later than the last week of November in the Central Valley. Camelina has broader temperature and moisture windows for germination and can be sown from October to December with less risk, but yields of camelina are lower than canola yields. In areas without irrigation, growers could plant canola opportunistically when seedbed conditions are favorable and use camelina as a fallback option.

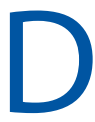
iversifying crops can improve farm economic performance, aid with weed and pest management, better utilize soil and water resources, and, in the case of Brassica oilseeds, provide benefits for pollinators. Growers have relatively few economically viable cool season crop options in California (USDA NASS 2012), but diversifying winter crop options may become more valuable if summer production of irrigated annual or short-term perennial species is limited by shortage of irrigation water, and potentially by climate change (Cayan et al. 2008; George and Kaffka 2017; Jackson et al. 2012).

On an area basis, wheat is the dominant cool-season crop in California (USDA NASS 2012, 2015). There has been long-standing interest in the potential of canola (Brassica napus), and other Brassica oilseed species, to diversify cereal-based cropping in California (Kaffka et al. 2015; Knowles et al. 1981). In a recent review, Angus et al. (2015) concluded that canola can have synergistic

Online: https://doi.org/10.3733/ca.2017a0019

Published online June 6, 2017
An early maturity variety of canola (center) grows next to late maturity varieties in a trial at the UC ANR West Side Research and Extension Center near Five Points. Using canola varieties that germinate reliably under either drier or colder soil conditions could potentially broaden the planting window and increase the number of years in which rain-fed production of canola is viable. 
effects on the productivity of wheat-dominated cropping. It benefits subsequent wheat crops by acting as a disease break, suppressing weed growth and providing more flexibility in herbicide choices.

Canola seed is used for the production of edible oil and high protein oilseed meal used for livestock feed.

It is also used for biodiesel production. At present, the demand for these products in the United States is larger than domestic production (FAOSTAT 2015; Johnson and Fritsche 2012; Newkirk 2009; USDA ERS 2014; USDA NASS 2015). Camelina (Camelina sativa) is another cool-season oilseed crop of interest to California growers. Currently, camelina is not widely used as a food for either humans or livestock, but it has been used for this in the past, and there is recent research directed towards this use (Betancor et al., 2015; Campbell et al., 2013; Cruz and Dierig 2015; Vollmann et al.

2007). At present, canola and camelina are not important crops in California. If used to diversify cool-season cropping, however, they could help sustain the longterm viability of California agriculture.

Under rain-fed production, the mean yield of canola in the Sacramento Valley (northern Central Valley) is predicted to be over 3,100 pounds per acre $(3,500$ kilograms per hectare) (George et al. 2017; George and Kaffka 2017). This should make canola, given suitable market development, economically competitive with wheat in the region (George et al. 2017; Winans et al. 2016).

Mean rain-fed yields of current camelina varieties are around 890 pounds per acre (1,000 kilograms per hectare) (George et al. 2017). Camelina is therefore unlikely to be economically competitive with wheat or canola, but it is regarded as a hardy crop, with low input requirements (Berti et al. 2016; Putnam et al. 1993), and recent field studies in California have shown it to be more cold and drought tolerant than canola (George et al. 2017). Camelina may therefore have a niche in production situations where canola and wheat are not viable due to low water availability or cold temperatures, especially if larger yields can be achieved reliably.

\section{Sowing time, establishment issues}

The development of a cool-season oilseed industry in California will require locally appropriate agronomic practices for reducing production risks and maximizing yield. In Mediterranean climates like California's, the appropriate fall sowing time is an important consideration for rain-fed production. It involves a trade-off between sowing late enough to reduce the risk of dry conditions during germination and establishment, and sowing early enough to optimize canopy leaf area at flowering, necessary for a high yield potential, and avoiding flowering and seed development during late spring, when hot and dry conditions are common (Farré et al. 2002; Farré et al. 2007; Hocking and Stapper 2001; Si and Walton 2004; Zeleke et al. 2014). Timely establishment in fall therefore increases the likelihood of a high yield for canola, assuming average rainfall and temperatures and suitable agronomic management (George et al. 2017; George and Kaffka 2017).

The ideal planting time for cool-season canola in California has been identified as between late October and early November (George and Kaffka 2017; Knowles et al. 1981), although the optimal time within this
A variety trial of canola several weeks after sowing at UC Davis. Researchers predict that canola yield in the Sacramento Valley could be over 3,100 pounds per acre under rain-fed production, which would make it economically competitive with wheat in the region.

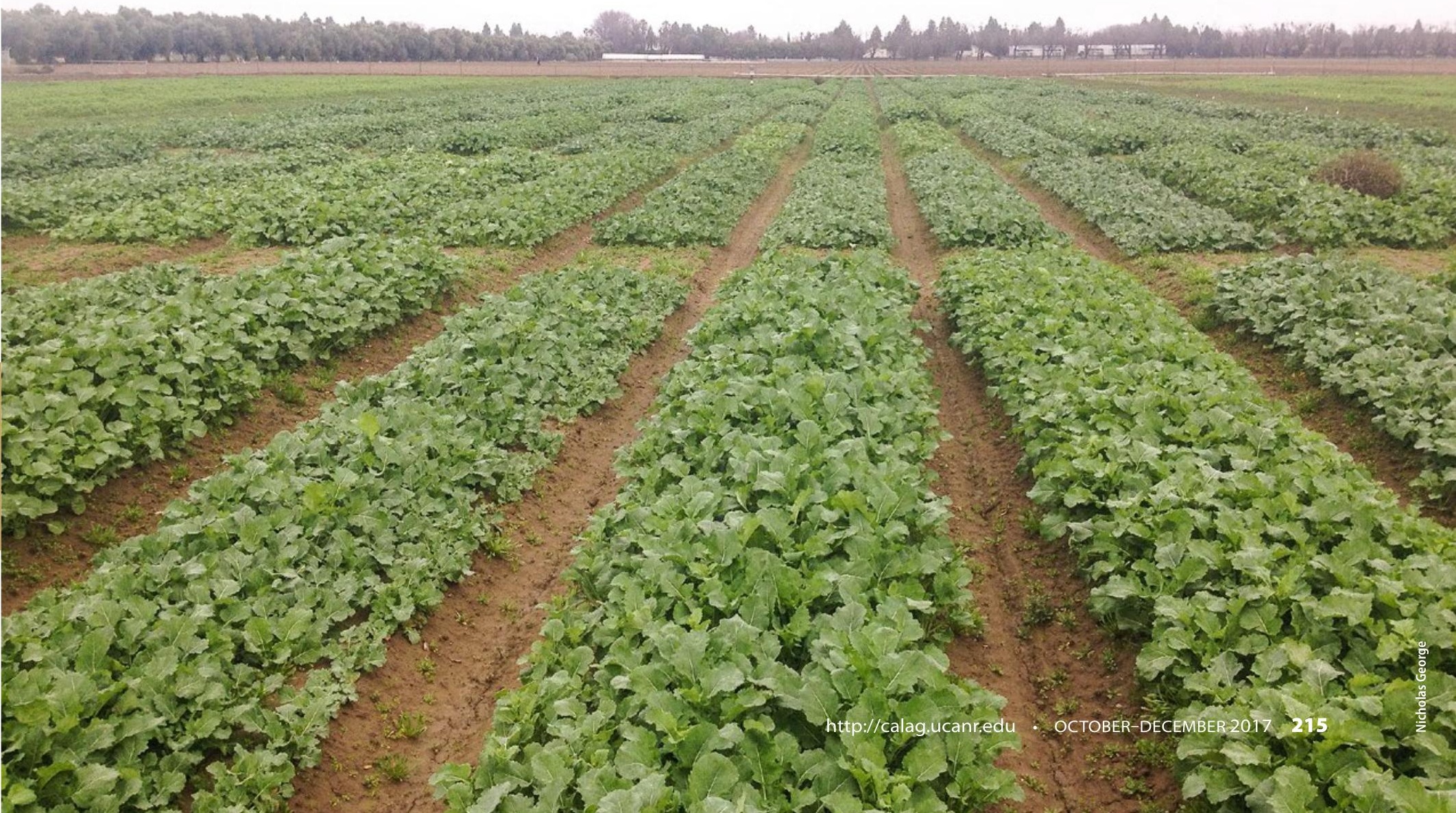


TABLE 1. The study assessed cool-season growing conditions in three agricultural regions in California

\begin{tabular}{|c|c|c|c|c|c|c|c|}
\hline Region & Site & Latitude & Longitude & $\begin{array}{l}\text { Years in climate } \\
\text { record }\end{array}$ & $\begin{array}{c}\text { Mean } \\
\text { temperature of } \\
\text { coldest month } \\
(\mathrm{Dec}) \\
{ }^{\circ} \mathrm{F}\left({ }^{\circ} \mathrm{C}\right)\end{array}$ & $\begin{array}{c}\text { Mean rainfall } \\
\text { Oct-Dec } \\
\text { inches }(\mathrm{mm})\end{array}$ & $\begin{array}{c}\text { Mean rainfall } \\
\text { Oct-May } \\
\text { inches }(\mathrm{mm})\end{array}$ \\
\hline \multirow{2}{*}{$\begin{array}{l}\text { Central } \\
\text { Coast }\end{array}$} & Atascadero & 35.47 & -120.65 & 13 & $46(8)$ & $1.0(24)$ & 12 (299) \\
\hline & San Luis Obispo & 35.31 & -120.66 & 27 & $54(12)$ & $2.2(55)$ & $19(485)$ \\
\hline \multirow{4}{*}{$\begin{array}{l}\text { Sacramento } \\
\text { Valley }\end{array}$} & Durham & 39.61 & -121.82 & 31 & $45(7)$ & $2.3(58)$ & $21(534)$ \\
\hline & Colusa & 39.23 & -122.03 & 31 & $45(7)$ & $1.5(39)$ & $16(400)$ \\
\hline & Davis & 38.60 & -121.54 & 31 & $45(7)$ & $2.0(51)$ & 17 (429) \\
\hline & Lodi & 38.13 & -121.39 & 14 & $46(8)$ & $1.3(33)$ & 14 (346) \\
\hline \multirow{5}{*}{$\begin{array}{l}\text { San Joaquin } \\
\text { Valley }\end{array}$} & Los Banos & 37.10 & -120.75 & 25 & $45(7)$ & $0.8(20)$ & $9(216)$ \\
\hline & Firebaugh & 36.85 & -120.59 & 16 & $45(7)$ & $0.7(17)$ & $10(247)$ \\
\hline & Parlier & 36.60 & -119.50 & 31 & $45(7)$ & $0.9(24)$ & $11(270)$ \\
\hline & Five Points & 36.34 & -120.11 & 31 & $46(8)$ & $0.9(23)$ & $8(208)$ \\
\hline & Kettleman City & 35.87 & -119.90 & 31 & $46(8)$ & $0.8(19)$ & $8(202)$ \\
\hline
\end{tabular}

period is unclear. Furthermore, poor establishment, and even total stand failure, of some but not all laterplanted canola crops has been an episodic problem observed in California (George et al. 2017; Kaffka et al. 2015). The reason for this has been unclear. In contrast, camelina sown at the same locations and times has not displayed establishment problems.

Canola seed can exhibit high germination percentages at soil temperatures as low as $40^{\circ} \mathrm{F}\left(4^{\circ} \mathrm{C}\right)$ (Chen et al. 2005; Edwards and Hertel 2011; Vigil et al. 1997), but under field conditions, sustained temperatures below $50^{\circ} \mathrm{F}\left(10^{\circ} \mathrm{C}\right)$ commonly result in low or delayed germination and subsequent poor establishment (Edwards and Hertel 2011; Nykiforuk and Johnson-Flanagan 1994, 1999; Vigil et al. 1997). In terms of water availability, over $90 \%$ germination of canola seed is generally achieved at a soil matric potential of $-0.4 \mathrm{MPa}$ or greater, and germination percentages then decline to zero between -0.4 MPa and -1.5 MPa (Blackshaw 1991; Williams and Shaykewich 1971).

By contrast, camelina is considered cold tolerant during germination (Allen et al. 2014; Berti et al. 2016; Putnam et al. 1993), with studies finding almost $100 \%$ germination and emergence at temperatures below freezing - although time to germination increases from approximately 9 days at $50^{\circ} \mathrm{F}\left(4^{\circ} \mathrm{C}\right)$ to 68 days at $30^{\circ} \mathrm{F}\left(-0.7^{\circ} \mathrm{C}\right)$ (Allen et al. 2014; Russo et al. 2010). Camelina also tolerates lower soil water during germination than canola, $90 \%$ germination of camelina has been observed at matric potentials as low as $-3.0 \mathrm{MPa}$, although seedling growth is more vigorous (based on root length) at water potentials over -1.5 MPa (Jiang 2013).

The establishment problems occasionally observed in California for canola, but not camelina, may therefore be due to fall seedbed conditions being episodically suboptimal for canola germination but usually suitable for camelina. To test this hypothesis, we examined the temperature and moisture conditions of seedbeds in potential oilseed production areas of California which largely overlap with current cereal cropping areas of the state - and assessed the frequency with which conditions suitable for germination of canola and camelina occur during the fall planting window for these crops.

The goal of the study was to identify risks associated with establishing canola and camelina in California under rain-fed conditions, suggest the best times and conditions for oilseed sowing and stand establishment in the region, and provide directions for future research.

\section{Sites, climate data}

Our analysis was designed to estimate the proportion of seasons in which soil moisture and soil temperature conditions were simultaneously suitable for the germination of canola or camelina at 11 locations throughout the Sacramento Valley (northern Central Valley), San Joaquin Valley (southern Central Valley) and Central Coast of California (table 1). These regions currently support cereal production and could incorporate canola or camelina production in the future. We considered data from a 31-year period (1983 to 2013), when suitable data (solar radiation, temperature, humidity, wind speed and precipitation) were available from the California Irrigation Management Information System (CIMIS 2015).

Previous work has found that the ideal sowing time for oilseeds in California is between October and November (George and Kaffka 2017; Knowles et al. 1981), so the time period we used for our analysis 
was Oct. 1 to Dec. 31, with December being the mean coldest month throughout most of the region. Some locations had climate records for fewer than 31 years. Analyses excluding these locations produced similar results to those including them, so all the locations were used in the final results.

\section{Soil temperature and moisture modeling}

Soil temperature and soil moisture information was not directly available for the regions of interest. We therefore used established modeling frameworks to estimate temperature and moisture time series at each location.

Soil water (measured in terms of the matric potential, the negative pressure associated with dry soils, which is directly linked to soil water content) was modeled using the Hydrus-1D Richards' equation solver. Richards' equation describes the flow of water through a variably saturated soil (Brutsaert 2005). The implementation of Richards' equation in Hydrus-1D has been extensively tested in representative soils from the Central Valley of California and shown to reproduce observed shallow soil water dynamics (Šimůnek et al. 2008).

Evaporative demand was estimated within the model using climate data (including solar radiation, temperature, humidity and wind speed). The evaporative data were then used to provide an atmospheric boundary condition to Richards' equation, which was solved to estimate soil water content (Brutsaert 2005).

The U.S. Department of Agriculture Natural Resources Conservation Service (USDA NRCS 2015) soils website was used to determine the most common soil types at each location. Loam soils were the dominant soil types, so soil matric potential was estimated to a depth of 1 inch ( 2.5 centimeters) for loam soil variants (loam, clay loam, silt loam and sandy loams) using the van Genuchten soil water retention model (Brutsaert 2005), with standard soil parameters available in Hydrus from Carsel and Parrish (1988). Initial soil moisture was set to the wilting point, assuming complete drying of the top 1 inch ( 2.5 centimeters) of the surface soil by the end of summer.

Canola and camelina seed are most commonly planted within 1 inch ( 2.5 centimeters) of the soil surface in flat fields with no soil cover (crop residue). No-till systems with residue cover were not modeled. Seedbed temperatures were estimated at the same study locations used for soil moisture estimation. We used the method proposed by Kätterer and Andrön (2008) and tested in California by Thompson et al. (2014). In this method, soil temperatures follow air temperatures, and their fluctuations lag with depth and soil thermal conductivity. With these assumptions, temperatures at 1 inch (2.5 centimeters) below the soil surface were estimated. Thermal conductivity of the soil was adjusted for changes in water content (wet soils conduct heat more effectively than dry soils), using the parallel

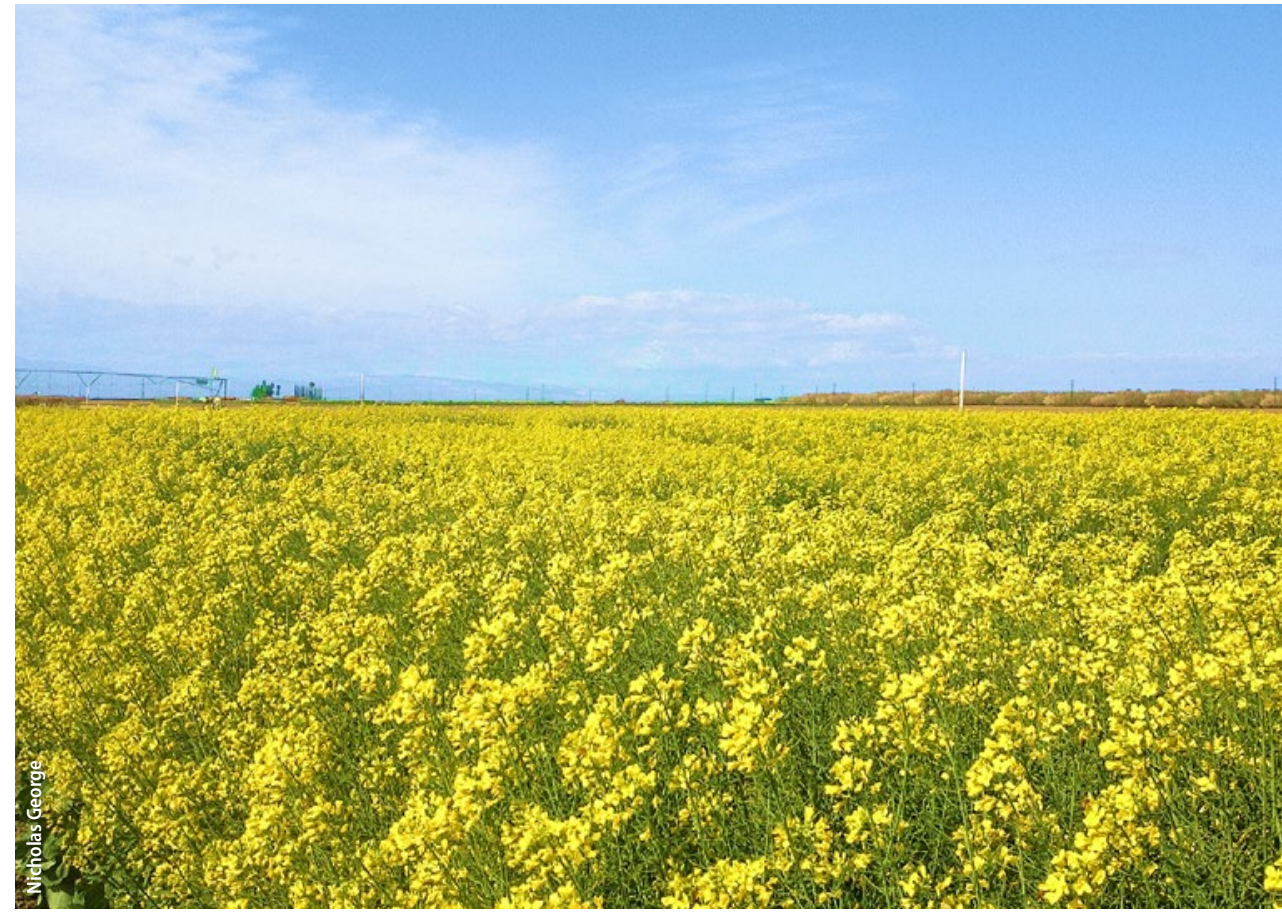

A field of canola in full bloom at West Side Research and Extension Center. A high canola yield is more likely if it is sown at the right time - it must be late enough in the fall that the risk of dry conditions during germination and establishment is low, and early enough to optimize canopy leaf area at flowering. gence behavior of canola and camelina in response to the variety of climate and soil conditions experienced throughout likely production regions in California.

\section{Germination thresholds}

To relate the modeled time series of soil moisture and temperature to seed germination and emergence likelihood, temperature and moisture ranges that support germination were identified from the literature. Based on these literature values, the minimum soil water threshold for canola germination was set to $-0.4 \mathrm{MPa}$, and to $-1.5 \mathrm{MPa}$ for camelina (Blackshaw 1991; Jiang 2013; Williams and Shaykewich 1971). Minimum soil temperature requirements for germination of canola and camelina were set to $50^{\circ} \mathrm{F}\left(10^{\circ} \mathrm{C}\right)$ and $40^{\circ} \mathrm{F}\left(4^{\circ} \mathrm{C}\right)$, respectively (Allen et al. 2014; Edwards and Hertel 2011; Nykiforuk and Johnson-Flanagan 1994, 1999; Russo et al. 2010; Vigil et al. 1997).

\section{Data analysis}

To explore the likelihood of optimal seedbed conditions occurring in the October to December planting window at each site, we counted the number of years in which temperature and moisture (treated both 
independently and jointly) exceeded the germination thresholds identified, for each day of the planting window. This enabled us to estimate the probability

Across all sites, suitable temperature and moisture conditions for canola germination were met
jointly in only $36 \%$ of years. correlated in the winter rainfall-dominated Mediterranean climate of California.

\section{Probability of good germination}

At the Central Valley locations, soil temperatures were predicted to drop below the $50^{\circ} \mathrm{F}\left(10^{\circ} \mathrm{C}\right)$ canola germination threshold by mid-November, and at coastal locations this threshold was crossed by December (fig. 1A). Based on seedbed temperature criteria alone, canola sown after the end of November in the Central Valley is likely to germinate well in fewer than $30 \%$ of years (fig. 1B). Camelina, by contrast, is likely to experience acceptable temperatures for germination to the end of November in most years, and through the end of December in $70 \%$ to $80 \%$ of years (fig. 1B).

The probability of soil moisture exceeding the minimum canola threshold for germination is less than 50\% until early November in the Sacramento Valley, and until early December in the San Joaquin Valley and Central Coast (fig. 1C). The probability of soil moisture exceeding the minimum camelina threshold for germination exceeds $50 \%$ by October (fig. 1C).

The joint probability of meeting temperature and moisture conditions simultaneously is shown in figure 1D. There is a relatively low probability that a seedbed on an arbitrarily selected day in the period from October to December will meet both temperature and moisture requirements for canola germination. Across all sites, suitable temperature and moisture conditions for canola germination were met jointly in only $36 \%$ of years. The probability of meeting the conditions simultaneously peaks around Nov. 15. Optimal conditions
(A) Estimated seedbed temperatures

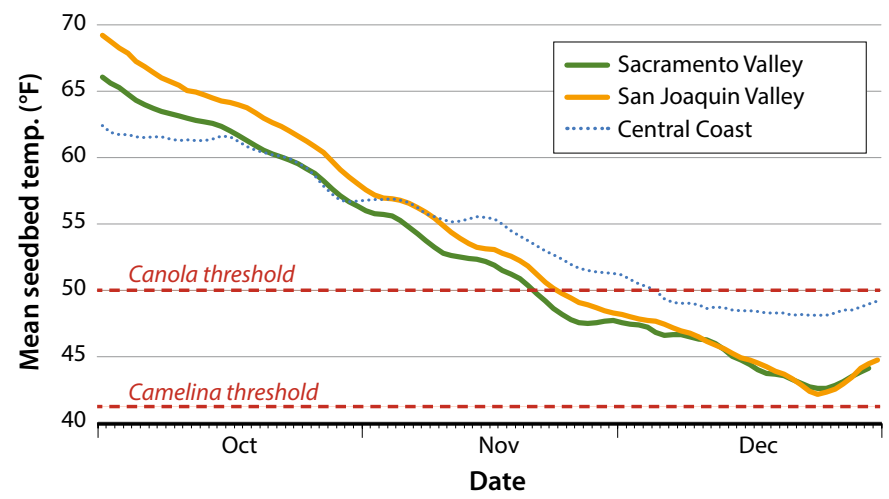

(C) Probability of seedbed moisture being above germination threshold

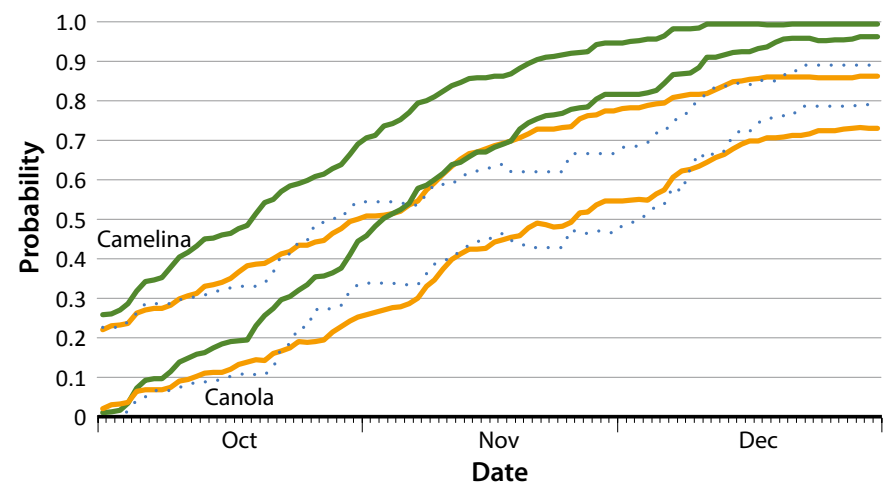

(B) Probability of seedbed temperature being above germination threshold

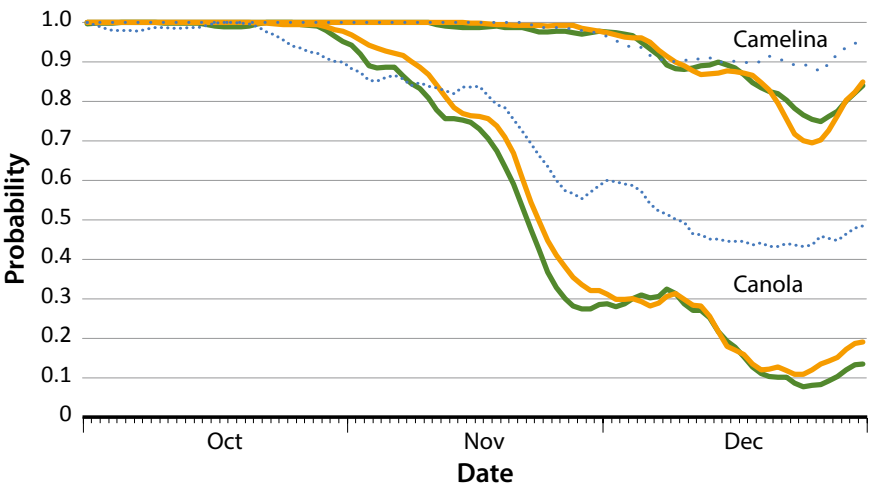

(D) Joint probability of both moisture and temperature being above germination thresholds

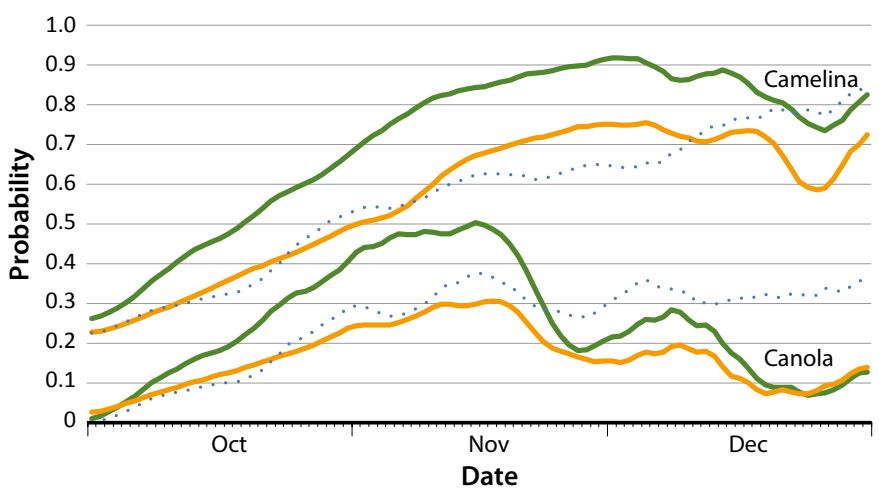

Fig. 1. (A) The estimated mean seedbed temperature, adjusted for moisture content, for different regions of California, relative to approximate minimum temperatures for germination of canola and camelina. (B) The probability of seedbed temperature being above the minimum temperature for germination for canola and camelina for different regions of California. (C) The probability of seedbed moisture being above the minimum water content for canola and camelina germination. (D) The joint probability of seedbeds meeting both the minimum matric potential and temperature requirements for germination of canola and camelina in different regions of California. 
for camelina are achieved in approximately $85 \%$ of years, and the probability of meeting both moisture and temperature conditions peaks on approximately Dec. 1.

\section{Establishment challenges}

Our modeling work supported the hypothesis that episodic problems with the establishment of some later-planted canola crops, and the acceptable establishment of camelina at the same locations, are due to seedbed conditions that are suboptimal for canola but not camelina. The Sacramento and San Joaquin Valleys showed similar temporal trends in temperature, moisture and the probability of jointly meeting moisture and temperature germination requirements. The Sacramento Valley has a higher probability of achieving minimum soil moisture thresholds than does the San Joaquin Valley, reflecting the earlier onset and higher average winter rainfall in that region. The Central Coast and San Joaquin Valley locations have a lower likelihood of achieving suitable soil moisture levels than the Central Valley but are predicted to stay warmer later in the season.

Based on seedbed temperatures only, canola should be sown no later than the end of November in the Central Valley and no later than the third week of November near the Central Coast. The number of growing degree-days following sowing needed for the emergence of canola is $80^{\circ} \mathrm{C}$ (base $0^{\circ} \mathrm{C}$ ) (Chen et al. 2005; Vigil et al. 1997), therefore a more conservative sowing date would be approximately a week earlier than those times. Under a best-case scenario, in approximately $50 \%$ of years in the Sacramento Valley and in the majority of years in the San Joaquin Valley and Central Coast, supplemental irrigation will be needed to ensure successful stand establishment (fig. 1D). In production situations with either water supply constraints or no ability to irrigate, canola should be planted opportunistically - under conditions of both sufficient rainfall and warm seedbed conditions. These conditions may exist only 1 in every 3 years, which requires growers to quantitatively monitor soil moisture and temperature during the planting season.

Under rain-fed farming conditions, camelina poses fewer risks during establishment than canola. The germination requirements of camelina, in terms of temperature and soil moisture, are likely to be met from October to December throughout the Central Valley and Central Coast. There may be a yield penalty associated with later sowing (for the same reasons as for canola), but this is not demonstrated in the research literature or empirically for California at present.

Camelina is not economically competitive with canola in California, due to its lower mean yields (George et al. 2017; Winans et al. 2016), but our analyses suggest that in locations or seasons where canola cannot be planted due to prevailing conditions, camelina represents a lower-risk oilseed option, particularly if yields can be increased reliably to the higher range of potential yields observed in field trials (George et al. 2017; Kaffka et al. 2015).

\section{Irrigation, new varieties, no-till}

The establishment challenges for canola identified here could be addressed through several approaches. Irrigation reduces risk during crop establishment and extends the growing season by permitting earlier sowing - which may be useful even in areas where the mean winter rainfall may be sufficient to support relatively high yields. Crop simulation modeling suggests irrigation is also important for increasing yields and minimizing variability for canola production in California (George and Kaffka 2017). Total irrigation requirements of canola and cool-season cereals are similar (George and Kaffka 2017; Jackson et al. 2006), and lower than the irrigation needs of many current warm-season crops.

Using canola varieties that germinate reliably under either drier $(<-0.4 \mathrm{MPa})$ or colder $\left(<50^{\circ} \mathrm{F} / 10^{\circ} \mathrm{C}\right)$ soil conditions could make planting viable earlier or later in the season. This would potentially broaden the planting window and increasing the number of years in which rain-fed production of canola is viable.

Screening for varieties that germinate reliably at lower temperatures or at deeper sowing depths, where

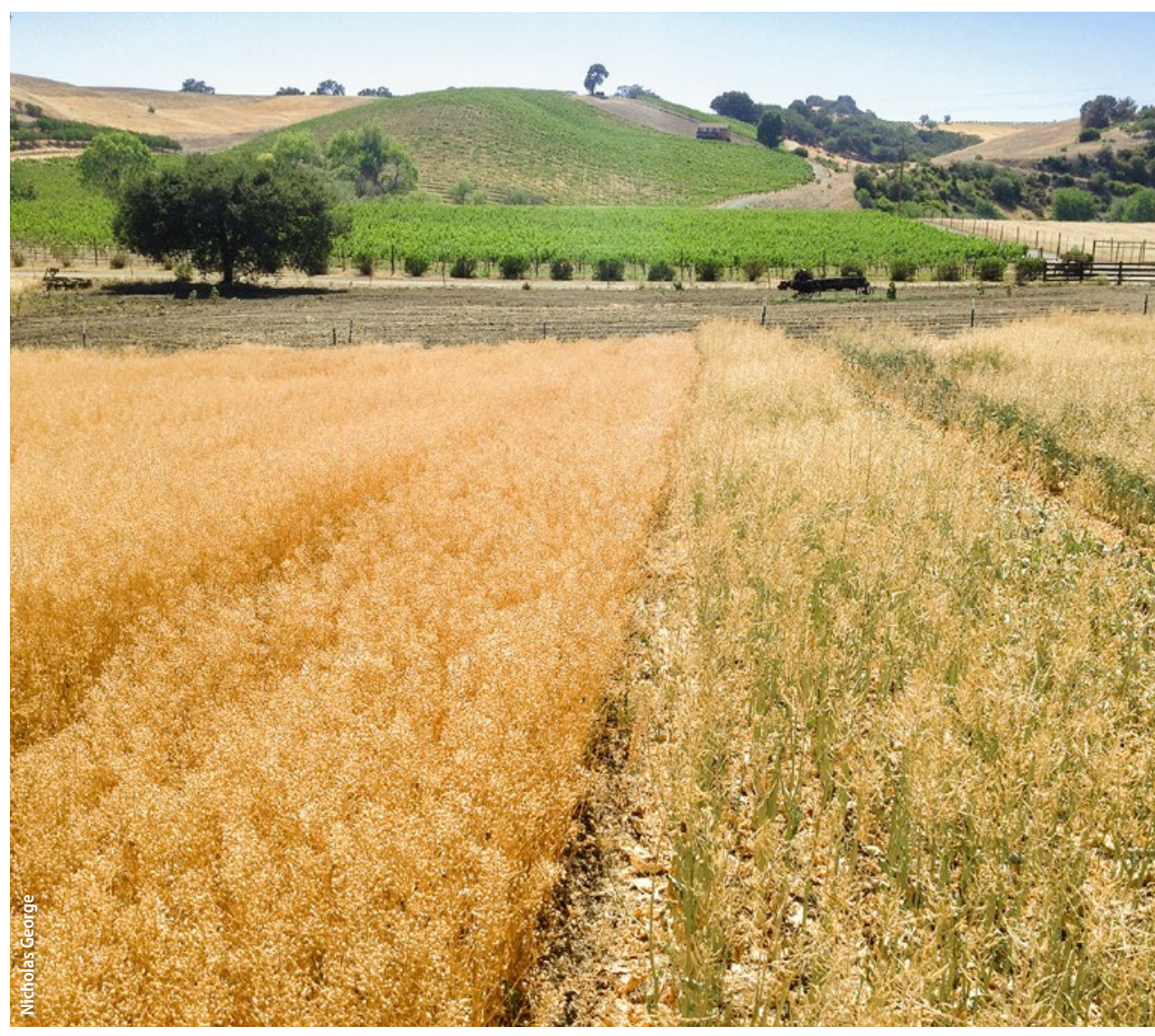

Although camelina has lower yields, it is more drought tolerant than canola and is a less risky option when canola cannot be planted as a result of suboptimal seedbed conditions. At Rossier Family Farm in Paso Robles, this field of camelina (left) produced a harvestable crop, while an adjacent field of canola (right) failed due to a lack of rain. 
soil temperatures will remain higher later in the season, would be valuable.

Agronomic management methodologies that increase soil water and temperature in early fall could also be considered as part of a canola production system. For example, canola could be produced using minimum- or no-tillage methods, which have been shown to preserve soil moisture in California (Mitchell et al. 2012). CA
N. George is Project Scientist and S. Kaffka is Assistant UC Cooperative Extension Agronomist in the Department of Plant Sciences at UC Davis; L. Levers is Postdoctoral Researcher in the Department of Environmental Sciences at UC Riverside; S. Thompson is Assistant Professor in the Department of Civil and Environmental Engineering at UC Berkeley; and J. Hollingsworth is Staff Research Associate at Kearney Agricultural Research and Extension Center, Parlier.

\section{References}

Allen BL, Vigil MF, Jabro JD. 2014. Camelina growing degree hour and base temperature requirements. Crop Ecol Physiol 106:940-4.

Angus JF, Kirkegaard JA, Hunt $J$ R, et al. 2015. Break crops and rotations for wheat. Crop Pasture Sci 66:523-52.

Betancor MB, Sprague M, Usher $S$, et al. 2015. A nutritionallyenhanced oil from transgenic Camelina sativa effectively replaces fish oil as a source of eicosapentaenoic acid for fish. Sci Rep 5:8104. doi:10.1038/ srep08104.

Berti M, Gesch R, Eynck C, et al. 2016. Camelina uses, genetics, genomics, production, and management. Ind Crop Prod 94:690-710.

Blackshaw RE. 1991. Soil temperature and moisture effects on downy brome vs. winter canola, wheat, and rye emergence. Crop Sci 31:1034-40.

Brutsaert W. 2005. Hydrology: An Introduction. Cambridge: Cambridge Univ. Pr.

Campbell MC, Rossi AF, Erskine W. 2013. Camelina (Camelina sativa (L.) Crantz): agronomic potential in Mediterranean environments and diversity for biofuels and food uses. Crop \& Pasture Science 64:388-98.

Carsel RF, Parrish RS. 1988. Developing joint probability distributions of soil water retention characteristics. Water Resour Res 24:755-69.

Cayan DR, Maurer EP, Dettinger MD, et al. 2008. Climate change scenarios for the California region. Climatic Change 87:s21-42.

Chen C, Jackson G, Neill K, et al. 2005. Determining the feasibility of early seeding canola in the Northern Great Plains. Agron $\rfloor$ 97:1252-62.

[CIMIS] California Irrigation Management Information System. 2015. California Department of Water Resources Office of Water Use Efficiency. http://wwwcimis. water.ca.gov/.
Cruz VMV, Dierig DA (eds.). 2015. Industrial Crops: Breeding for Bioenergy and Bioproducts. Springer: New York. 453 p.

Edwards J, Hertel K. 2011 Canola Growth and Development. State of New South Wales Department of Primary Industries.

FAOSTAT. 2015. Food and Agriculture Organization of the United Nations. http://faostat3. fao.org.

Farré I, Robertson M, Asseng S. 2007. Reliability of canola production in different rainfall zones of Western Australia. Aust J Agr Res 58:326-34

Farré I, Robertson MJ, Walton GH, Asseng S. 2002. Simulating phenology and yield response of canola to sowing date in Western Australia using the APSIM model. Aust J Agr Res 53:1155-64

George N, Hollingsworth J, Yang W-R, Kaffka S. 2017. Canola and camelina as new crop options for cool-season production in California. Crop Sci 57(2):693-712.

George NA, Kaffka SR. 2017. Canola as a new crop for California: A simulation study. Agron J 109(2):496-509.

Hocking PJ, Stapper M. 2001 Effects of sowing time and nitrogen fertiliser on canola and wheat, and nitrogen fertiliser on Indian mustard. I. Dry matter production, grain yield, and yield components. Aust J Agr Res 52:623-34.

Jackson L, Fernandez B, Meister H, Spiller M. 2006. Small Grain Production Manual. UC ANR Pub 8208. Oakland, CA. 110 p

Jackson L, Haden VR, Wheeler SM, et al. 2012. Vulnerability and Adaptation to Climate Change in California Agriculture. California Energy Commission Pub CEC-500-2012-031. www.energy.ca.gov/2012publications/ CEC-500-2012-031/CEC-5002012-031.pdf. 114 p.
Jiang Y. 2013. Effect of Environmental and Management Factors on Growth and Seed Quality of Selected Genotypes of Camelina sativa L. Crantz.

MSc dissertation. Department of Agriculture, Dalhousie Univ., Halifax, Nova Scotia.

Johnson GH, Fritsche K. 2012. Effect of dietary linoleic acid on markers of inflammation in healthy persons: A systematic review of randomized controlled trials. J Acad Nutr Dietetics 112:1029-40.

Kaffka S, Zhang J, George N, et al. 2015. Winter Annual Oilseed Crop Evaluation: 2009-2013. Canola, Camelina, and Meadow foam. UC Davis Agronomy Research and Information Center. http://oilseeds.ucdavis.edu.

Kätterer T, Andrön O. 2008. Predicting daily soil temperature profiles in arable soils in cold temperate regions from air temperature and leaf area index. Acta Agriculturae Scandinavica, Section B - Soil Plant Sci 59:77-86.

Knowles PF, Kearney TE, Cohen DB. 1981. Species of rapeseed and mustards as oil crops in

California. In: Pryde EH, Princen LH, Mukherjee KD (eds.). New Sources of Fats and Oils. Champaign, IL: American Oil Chemists Society. p 255-68.

Mitchell JP, Sing PN, Wallender WW, et al. 2012. No-tillage and high-residue practices reduce soil water evaporation. Calif Agr 66:55-61.

Newkirk R. 2009. Canola Meal: Feed Industry Guide. Canadian International Grains Institute, Winnipeg, Canada. 48 p.

Nykiforuk CL, Johnson-Flanagan AM. 1994. Germination and early seedling development under low temperature in canola. Crop Sci 34:1047-54

Nykiforuk CL, Johnson-Flanagan AM. 1999. Storage reserve mobilization during low temperature germination and early seedling growth in Brassica napus. Plant Physiol Bioch 37:939-47.
Putnam DH, Budin JT, Field LA Breene WM 1993. Camelina: A promising low-input oilseed. In: Janick J, Simon JE (eds.). New Crops. New York: Wiley. p 314-22.

R Core Team. 2016. R: A language and environment for statistical computing. R Foundation for Statistical Computing, Vienna, Austria. www. R-project. org/.

Russo VM, Bruton BD, Sams CE. 2010. Classification of temperature response in germination of brassicas. Ind Crop Prod 31:48-51.

Si P. Walton GH. 2004. Determinants of oil concentration and seed yield in canola and Indian mustard in the lower rainfall areas of Western Australia. Aust J Agr Res 55:367-77.

Šimůnek J, van Genuchten MT, Šejna M. 2008. Development and applications of the HYDRUS and STANMOD software packages and related codes. Vadose Zone J 7:587-600.

Thompson SE, Levin S, Rodriguez-Iturb I. 2014. Rainfall and temperature changes have confounding impacts on Phytophthora cinnamomi occurrence risk in the southwestern USA under climate change scenarios. Global Change Biol 20:1299-312

[USDA ERS] US Department of Agriculture Econbomic Research Service. 2014. Oil Crops Yearbook. Fats and Oils: Production, Consumption and Stocks. USDA, Economic Research Service estimates and US Census Bureau.

[USDA NASS] US Department of Agriculture National Agricultural Statistics Service. 2012. California Agricultural Statistics, 2012 Crop Year. USDA NASS, Pacific Regional Office-California, Sac ramento, California. 100 p.

USDA NASS. 2015. National Agricultural Statistics Service. www.nass.usda.gov/.

[USDA NRCS] US Department of Agriculture Natural Resources Conservation Service. 2015. Web Soil Survey. http://websoilsurvey.nrcs.usda.gov/app/ HomePage.htm.

Vigil MF, Anderson RL, Beard WE. 1997. Base temperature and growing-degree-hour requirements for the emergence of canola. Crop Sci 37:844-9.

Vollmann J, Moritz T, Kargl C, et al. 2007. Agronomic evaluation of camelina genotypes selected for seed quality characteristics. Ind Crop Prod 26:270-77.

Williams J, Shaykewich CF. 1971. Influence of soil water matric potential and hydraulic conductivity on the germination of rape (Brassic napus L.). J Exp Bot 22:586-97.

Winans K, Yeo B-L, George N, et al. 2016. A regional assessment of land, irrigation water, and greenhouse gas emissions from canola biodiesel feedstock production in California. In: Proc Int Symp on Sustainable Systems and Technologies, SSST, v4, May 15-16, 2016. Phoenix AR. http://doi.org/10.6084/ m9.figshare.4047435.

Zeleke KT, Luckett DJ, Cowley RB. 2014. The influence of soil water conditions on canola yields and production in South- 